Comparative Philosophy Volume 7, No. 1 (2016): 59-89

Open Access / ISSN 2151-6014

www.comparativephilosophy.org

\title{
BUDDHIST PHENOMENOLOGY AND THE PROBLEM OF ESSENCE
}

\author{
JINGJING LI
}

\begin{abstract}
In this paper, I intend to make a case for Buddhist phenomenology. By Buddhist phenomenology, I mean a phenomenological interpretation of Yogācāra's doctrine of consciousness. Yet, this interpretation will be vulnerable if I do not justify the way in which the anti-essentialistic Buddhist philosophy can countenance the Husserlian essence. I dub this problem of compatibility between Buddhist and phenomenology the "problem of essence". Nevertheless, I argue that this problem will not jeopardize Buddhist phenomenology because: (1) Yogācārins, especially later Yogācārins represented by Xuan Zang do not articulate emptiness as a negation but as an affirmation of the existent; (2) Husserl's phenomenological essence is not a substance that Yogācārins reject but the ideal sense (Sinn) that Yogācārins also stress. After resolving the problem of essence, I formulate Buddhist phenomenology as follows: on the epistemological level, it describes intentional acts of consciousness; on the meta-epistemological level, it entails transcendental idealism.
\end{abstract}

Keywords: essence, emptiness, later Yogācāra, transcendental idealism, Buddhist phenomenology

\section{INTRODUCTION}

In Ideas 1, Husserl defines phenomenology as the science of essence, not the science of matters of facts (Hua 3/5). This demarcation marks his turn from descriptive phenomenology (the study that factually analyzes real psychological phenomena) to transcendental phenomenology (the theory that explains essential ideal conditions that make real psychological phenomena possible). Regardless of this turn, Husserl uses phenomenology as the approach to consciousness. He describes human consciousness to be the intentional awareness constituted by subjects in their interaction with objects that appear as mental phenomena. Here, then, goes Husserl's slogan: consciousness is the consciousness of something for someone.

This conception of consciousness in Husserl permits, at least in principle, the possibility of comparative studies between Husserl's phenomenology and Yogācāra

LI, JINGJING: PhD Candidate, Faculty of Religious Studies, McGill University, Canada.

Email: Jingjing.li2@mail.mcgill.ca 
Buddhism. Characterized by its doctrine of vijñāptimātra (Consciousness-only), Yogācāra Buddhism (henceforth Yogācāra) has been a major Mahāyāna Buddhist school since 300s CE. According to the Chinese Yogācārin Xuan Zang (Hsüan-tsang, 玄牀, 602CE- 664CE), Yogācārins conceive of consciousness as "vijñāpti (liao-bie, 了 别)" (T31N1585, P1a29). This Sanskrit term 'vijñapti' literally means the act that causes someone to know something distinctly (Hall 1986, 8).

Many scholars remark that Yogācāra's definition of consciousness is very close to Husserl's, not just from the phenomenological tradition (Iso Kern, Ni Liangkang, Zhang Qingxiong, etc.) but also from the Buddhist one (Lin Chen-kuo, Yao Zhihua, Dan Lusthaus, Dan Arnold etc.). Phenomenologists depict consciousness as that of something for someone and Yogācārins demarcate consciousness as that which lets someone to know something. For both, consciousness correlates subjective acts of knowing with objects to be known.

For instance, Dan Arnold defines consciousness through intentionality or "aboutness". By aboutness, Arnold means that consciousness is always about certain objects (Arnold 2012, 7). According to Arnold, both modern philosophers of mind, including Husserl and Yogācārins such as Dharmakīti in 600s CE endorse the intentional account of consciousness. Refusing to enclose consciousness in the mind, Evan Thompson and Francisco Varela argue that consciousness is what we enact in our bodily experience (Thompson and Varela 1991, xvi). Since this embodied account of consciousness is not fully developed in the West, Thompson and Varela turn to Madhyamaka Buddhism (henceforth Madhyamaka), a doctrine that is nonwestern but more practical. Iso Kern and Ni Liangkang find it not enough to define consciousness on the descriptive level, be it aboutness or embodiment. To complement the definition, Kern and $\mathrm{Ni}$ inquire into conditions that make these intentional acts possible on the interpretive level. Now that both Husserl and Yogācārins demarcate consciousness on these two levels, Kern is convinced of the "universality" of Husserl's phenomenology (Kern 2012, 154). Following Kern, Ni articulates the two-level as a "twofold structure" : intentionality on the surface and subjective ideality deep down ( $\mathrm{Ni} 2010,81-84)$. Under this conception of consciousness, Ni puts forward his comparative project called "Consciousness-only phenomenology" that infuses textual analysis in Yogācāra with Husserl's factual analysis (Ni 2010, 81-86).

\footnotetext{
${ }^{1} \mathrm{Ni}$ argues that "although Yogācāra Buddhism does not directly adopt any concept similar to 'intentionality' in Phenomenology in the analysis of consciousness, it still shares many common points with Phenomenology", among which $\mathrm{Ni}$ enumerates five similarities: enacting reflection or introspection in the analysis of consciousness; deconstructing the subject-object dichotomy; adopting reduction as the method; advocating the twofold structure of consciousness, twofold as the surfacestructure and the deep-structure; recognizing the relation between objectivating and non-objectivating or between the founding and the founded acts (Ni 2010, 81-84). In the meantime, Ni also clarifies the differences between Yogācāra and Husserl: 1) Yogācāra philosophy contains more practical, more moral elements than Husserl's Phenomenology; 2) due to its religiosity, Yogācāra accounts for consciousness in the hope of justifying Buddhist faith whereas Husserl's phenomenology is a rigorous science; 3) after explicating the constitution of consciousness, Yogācāra proceeds to negating subjectivity, a step that is not advanced by Husserl (Ni 2010, 84-86).
} 
Most comparative scholars expect their studies to open dialogues between the East and the West. Under this expectation, they treat, consciously or unconsciously, Husserl's phenomenology and Yogācāra philosophy as two separate entities. Notably, Dan Lusthaus disputes this dualistic approach in his Buddhist Phenomenology ${ }^{2}$ (Lusthaus 2003, vi). As Lusthaus claims, he does not want to pose a dichotomy between Yogācāra on the one hand and phenomenology on the other (Lusthaus 2003, vi). Rather, he translates Yogācāra Buddhism to a transcendental phenomenology in the Husserlian sense (Lusthaus 2003, viii). This translation is referred to by Lusthaus as 'Buddhist Phenomenology' the mission of which is to bridge gaps between eastern and western cultures (Lusthaus 2003, vii).

Regardless of his fruitful findings, I find Lusthaus's project vulnerable to one meta-epistemological ${ }^{3}$ problem that has been discerned by many comparative scholars cited above. Arnold contrasts Dharmakirti's "epistemic idealism" with the "cognitive-scientific physicalism" in modern philosophy of mind (Arnold 2012, 11 17). Thompson and Varela suspend discussions as such insofar as they do not intend to establish a unified mind-body theory (Thompson and Varela 1991, xviii). Ni also eschews contradictions between Husserl and Yogācāra by orienting his Consciousness-only phenomenology towards epistemology.

I dub this meta-epistemological problem the 'problem of essence'. Buddhist philosophy rejects any type of essentialism, due to Buddha's teaching of emptiness. According to this teaching, all objects, be it the world or the human self, do not have permanent essence. To the contrary, Husserl formulates his phenomenology as the science of essence that stresses the importance of subjectivity. Given these two different attitudes towards essence, how can we advocate such a Buddhist phenomenology both as a science of essence and as an anti-essentialistic philosophy of religion? Or, how can we justify the compatibility between the phenomenological essence and Buddha's teaching of emptiness?

Most comparative scholars evade this problem by focusing on the epistemological side of Yogācāra and phenomenology. In this way, they can remain neutral towards meta-epistemological issues. Yet, if we follow Lusthaus, we must confront the problem of essence so as to defend Buddhist phenomenology against it. I plan to

\footnotetext{
${ }^{2}$ To contrast Lusthaus's 'Buddhist Phenomenology', I do not put 'phenomenology' in its upper case in my articulation of 'Buddhist phenomenology'.

${ }^{3}$ By 'meta-epistemological', I mean any metaphysical and ontological presuppositions prior to epistemology. I deliberately avoid the term 'ontological' or 'metaphysical' for two reasons. First, many Buddhist scholars doubt whether we can directly transport these western philosophical terms into Buddhism because 'ontology' or 'metaphysics' carries substantial meaning and this meaning contradicts Buddha's teaching of emptiness (Xia 2002, 133-139; Fu 2002, 15-27). Second, in the Husserlian scholarship, a term as "ontological" or "metaphysical" also becomes problematic because Husserlians are still debating over Husserl's attitude to metaphysics. I will come back to this debate in section three.

${ }^{4}$ Arnold worries that Dharmakīti (as an anti-physicalist and an idealist) is vulnerable to his own critique of physicalism. Arnold's main argument is that: since Dharmakīrti affirms the function of causal laws, he shares partly the worldview of physicalists; then, how could Dharmakirti validly critique physicalists when his view does not differ too much from the latter? (Arnold 2012, 47).
} 
resolve this problem by demarcating the sense in which Yogācāra's ${ }^{5}$ account of emptiness, with particular focus on that in Xuan Zang, countenances the Husserlian essence.

On the Buddhist side, I contend that later Yogācārins, unlike Mādhyamikas and early Yogācārins, advocate a positive view of the existent because they attribute nominal existence to illusory dharmas and real existence, though not in a substantial sense, to consciousnesses. By this positive articulation, they remedy the problematic accounts of emptiness in Madhyamaka and early Yogācāra. On the phenomenological side, Husserl formulates essence as the ideal meaning or sense (Sinn) that ensures objectivity of mental phenomena in subjective consciousness, not as any a-spatiotemporal substance. Since Yogācāra's emptiness is not a void and the Husserlian essence is not a substance, we can resolve the problem of essence. Subsequently, I rearticulater Yogācāra Buddhism as a transcendental phenomenology in the Husserlian sense: epistemologically it enriches Husserl's account of intentional consciousness and meta-epistemologically it conforms to Husserl's transcendental idealism 6 .

To tackle the problem of essence, I also expose my paper to many controversies. The first controversy concerns the Orientalistic ${ }^{7}$ romanticization of religions: scholars

\footnotetext{
${ }^{5}$ Since half of my paper is about Yogācāra, I want to carefully define this term. Yogācāra, as most Buddhist schools, accommodates various sectarian differences, far from being a school of homogeneous views. Keeping in mind these sectarian differences, I highlight the distinction between early Yogācāra (wei-shi-jin-xue, 唯識今學) and later Yogācāra (wei-shi-gu-xue, 唯識古學), a topic I will come back to in section two. In particular, I show that it is not early Yogācāra but later Yogācāra that eventually resolves inconsistencies in Madhyamaka's account of emptiness. Besides, I do not think it is possible for me to advocate an overall compatibility between Buddhism and Husserl's phenomenology. Here, I have put aside anther doctrinal debate among Buddhists on whether Yogācārins embrace essentialism and thus violate Buddha's teaching of emptiness.

${ }^{6}$ I will elaborate the meaning of transcendental idealism later in section three. Here, I want to highlight the difference between early Yogācārins and later Yogācārins on their respective meta-epistemological positions. Scholars are still debating on the way in which we can properly demarcate Yogācāra's idealism. Lambert Schmithausen interprets it as a metaphysical idealism - "there are no entities, especially no material entities, apart from consciousness, or more precisely, apart from the various kinds of mind (citta) and mental factors or mind-associates (caitta)" (Schmithausen 2005, 1). Ashok Kumar Chatterjee considers it as an absolute idealism so that Yogācāra can surpass Madhyamaka's dialectical idealism (Chatterjee 1962, 27-28). Alex Wayman casts doubt on Chatterjee's reading of "consciousness as the sole reality" because the idealism in Yogācāra is as such "in respect to content, this system is realistic; in respect to form, it is idealistic" (Wayman 1965, 67). Thomas Kochumuttom prefers to dub it 'realistic pluralism', not 'monistic idealism' (Kochunuttom 1982, 21). Dan Lusthaus portrays it as transcendental idealism. Most scholars acknowledge Yogācāra's critique of metaphysical realism. Before advocating my own interpretation, I want to point out one factor that causes the perplexity of Yogācāra's idealism, that is, Yogācārins offer at least two meta-epistemological theories. As I shall show in the conclusion, while early Yogācāra embraces metaphysical idealism, later Yogācāra advocates transcendental idealism. Due to this contrast, I would be hesitated to bring Yogācāra's idealism under one brand. Besides, Lusthaus did not give a clear definition of transcendental idealism. Due to the unclarity, Lusthaus's interpretation of Yogācāra has been defied by scholars like Schmithausen.

${ }^{7}$ I use the term Orientalistic, not Orientalist because I intend to accommodate two different but related vantage points. One is Orientalism that posits the duality between the rational West and the non-
} 
usually posit a dichotomy between the non-rational East and the rational West in intercultural dialogues. While remaining neutral to this dichotomy, I agree on Robert Sharf's critique that by romanticizing, scholars over-homogenize eastern and western thoughts (Sharf 1993, 43).

The second issue is referred to as the "cult of nothingness" by Roger-Pol Droit, that is, scholars often inappropriately simplify Buddha's teaching of emptiness to a negation of the world and the self (Droit 2003, 22-23). Doctrinally, however, as I will show in this paper, Buddhists develop much more complicated accounts of emptiness than a "cult of nothingness". Not just do Yogācārins disagree with Mādhyamikas, even inside the Yogācāra School, early Yogācārins and later Yogācārins have debated on the demarcation of emptiness.

Amid the third controversy, scholars question Chinese Buddhism's authenticity. Many of them regard Chinese Buddhism as an inauthentic sinicization of Indian Buddhism (Ch'en 1973, 5; Zürcher 2007, 4). While not engaging with this issue of authenticity, I support Lin's view that the Chinese scholarship on Yogācāra has long been ignored but these resources will contribute to contemporary studies on Yogācāra (Lin 1999, 231-247).

\section{EMPTINESS IN MADHYAMAKA AND YOGĀCĀRA}

In this section, I elucidate Xuan Zang's conception of emptiness by contextualizing his thought in the historical development from Madhyamaka to Yogācāra. Here, I rework Xuan Zang's narrative to show that Mādhyamikas bring many inconsistencies in their view of emptiness that are resolved not by early Yogācārins but by later Yogācārins. For this reason, Xuan Zang elevates later Yogācārins' explication of emptiness as the optimal.

Xuan Zang advocates this narrative in his sütra classification framework (panjiao, 判教): the Buddha preaches Hīnayāna dharmas on the four noble truths that prepare audience for Madhyamaka's secretive saying on "all dharmas are empty", but the Buddha finalizes the preaching with Yogācāra's "direct explicating of threenature and the principle of non-empty suchness"8 (T45N1866, P481a14-20). Buddhist

rational East. The other is the reversed Orientalism that appropriates the Orientalist duality but reverses it to argue for the superiority of non-rational East over rational West.

${ }^{8}$ Fazang writes in the Paragraphs on the Doctrine of Difference and Identity of the One Vehicle of Huayan (Huayan-yi-cheng-jiao-fen-qi-zhang, 華嚴一乘教分齊章) that “the tenth way [of sütra classification] comes from Xuan Zang, the Tang Dynasty Tripitaka Master. Following the Samdhinirmocanasūtra, the Suvarnaprabhāsottamarājasūtra, and the Yogācārabhūmiśāstra, he classifies [Buddha's teachings into] three canons, namely, the three dharma-wheels. The Buddha turned the dharma-wheel for the first time in the deer-garden when the Buddha preached on the four noble truths. This preaching is about the dharmas of Hīnayāna. The Buddha then illuminated the dharma-wheel for the second time in the Mahāyāna tradition when the Buddha secretively said that 'all dharmas are empty' etc. The Buddha held the dharma-wheel for the third time inside the Mahāyāna tradition when the Buddha directly explicated the three-nature and the principle of non-empty suchness etc. (十依大唐三藏玄奘法師。依解深密經金光明經及瑜伽論。立三種教。即三法輪是也。一轉 法輪。謂於初時鹿野園中。轉四諦法輪。即小乘法。二名照法輪。謂中時於大乘內密意說言諸 
clergy in China use pan-jiao to organize sütras translated in various periods, in the hope of managing discrepancies within these theories. Xuan Zang, in his pan-jiao, accounts for the discrepancy between Madhyamaka and Yogācāra like this Madhyamaka's secretive saying (mi-yi-shuo, 密意說) is in consistency, not in rupture, with Yogācāra's direct explicating (liao-yi-shuo, 了意說) if we understand Yogācāra' explication as an amelioration of Madhyamaka's' .

At the beginning of Vijñäptimātratāsiddhi (cheng-wei-shi-lun, 成唯識論, henceforth Siddhi) Xuan Zang alludes to this narrative through the two reasons for Yogācārins to preach on emptiness: (1) clearing the wrong views of conceiving the self and the world as the svabhāva; (2) promoting the correct view of Consciousnessonly. By these two reasons, Xuan Zang confirms the therapeutic goal of Buddhism emptiness cures suffering. Moreover, for Xuan Zang, compared with later Yogācārins' articulation (for whom, both the self and objects are illusions constantly transformed by consciousness), other readings of emptiness ${ }^{10}$, such as those from

法空等。三名持法輪。謂於後時於大乘中顯了意說三性及真如不空理等)” (T45N1866, P481a1420). According to Tang Yongtong, Fazang used to assist Xuan Zang with sūtras translations in Ci'en Temple but resigned due to their different understandings on Buddha's teachings (Tang 2000, 174). We can infer that Fazang was very familiar with Xuan Zang's preaching so that Fazang's record can be trustworthy.

${ }^{9}$ Many verses in the Siddhi support Fazang's record. We locate one of them in the section on the threenon-nature (trinihsvabhāvatā). Here, Xuan Zang poses the question: "if there are three natures, why the World Honored preaches that 'all dharmas are not svabhāva' (若有三性。如何世尊說一切法皆 無自性) (T31N1585, P47c24)". Xuan Zang answers that this saying from the Buddha is articulated only in the secretive way, not in the explicit manner. Explicitly, it is not that all dharmas do not have any nature - dhamas do have certain nature, albeit this nature is not the own nature qua svabhāva (T31N1585, P48a5-6).

${ }^{10}$ For the translation of Xuan Zang's Siddhi, I have consulted Louis de la Vallée Poussin's French translation and Francis H. Cook's English translation. At the beginning of the Siddhi, Xuan Zang writes about the purposes of Vasubandhu's Trimsíikavijñaptikārika . The first purpose is "for those who do not fully comprehend (mi, 迷, vipratipanna) or wrongly understand (miu, 謬, apratipanna) the two empties (二空, pudgalaśünyatā, dharmaśūnyatā) to acquire correct comprehensions. The correct comprehensions are for the detachment from two strong hindrances (avarana). The two hindrances are generated by the two attachments (ätmangrāha, dharmagrāha). If the two empties are realized, the hindrances will be detached (今造此論為於二空有迷謬者生正解故。生解為斷二重障故。由我法 執二障具生。若證二空彼障隨嵫) (T31N1585, P1a9-10). The second purpose is “for those, who wrongly attach to the permanent self (ätman) and to permanent objects (dharma) and for those who do not fully understand Consciousness-only (vijñāptimätra), to realize the two empties and to truly know the meaning of Consciousness-only (又為開示謬執我法迷唯識者。令達二空。於唯識理如實知故) (T31N1585, P1a13-14)". The last purpose is "for those who do not fully comprehend or wrongly understand the meaning of Consciousness-only. Those people either consider external objects (bähyārtha) as consciousness which are not inexistent; or regard inner consciousness as external objects which are not existent; or consider that all consciousnesses derive from one original consciousness, albeit these various consciousnesses have respective functions; or regard mental factors without citta to be the non-existent. Vasubandhu intends to refute these diverse wrong conceptions in order to promote the true understanding of the profound and wondrous meaning of Consciousness-only (復有迷謬唯識理者。或執外境如識非無。或執內識如境非有。或執諸識用別體同。或執離心無 別心所。為遮此等種種異執。令於唯識深妙理中得如實解故作斯論) ( T31N1585, P1a14-18)”. 
Sarvāstivādins (for whom, external world has real existence), from Mādhyamikas (for whom, inner consciousness does not exist at all), and from early Yogācārins (for whom, there is an original consciousness that serves as the condition for all dharmas), are just not-so-correct (T31N1585, P1a13-18).

By focusing on the conception of emptiness, I re-articulate Xuan Zang's narrative as follows: Hīnayānas do not understand emptiness as the negation both of the permanent self and of the permanent world; Mãdhyamikas attain the correct understanding of emptiness but their secretive saying contains inconsistencies; early Yogācārins do not fully distance themselves from Mādhyamikas so that they fail to resolve these inconsistencies; only later Yogācārins ameliorate Mādhyamikas' secretive saying by their direct explicating. For this reason, Xuan Zang elevates later Yogācārins' interpretation of emptiness to the most ideal.

Now, let us revisit the account of emptiness in Madhyamaka, its advance from Hīnayāna, and its problems. This negative approach to emptiness unfolds primarily in Nāgārjuna's Mūlamadhyamakakārikā (zhong-lun, 中論, henceforth MMK). Nāgārjuna contests the opposition between emptiness and dependent co-arising by portraying coarising as "neither arising nor perishing; neither permanent nor terminate; neither identical nor different; neither coming nor going" 11 (T30N1564, P1b14-15). A portrait as such alludes to Nāgārjuna's middle way - emptiness is neither identical with nor different from illusions. By illusions, I do not mean wrong perceptions. Nor do I use illusion to translate a specific Buddhist term. Rather, I consider illusions as dharmas that dependently co-arise, seeming to be permanently real ${ }^{12}$. For Nāgārjuna, emptiness sublates dualistic views between being/arising and non-being/perishing.

As per Vallée Poussin, these three purposes are articulated respectively by Sthiramati, Citrabhānu, and Dharmapāla in their interpretations of Vasubandhu (Vallée Poussin 1928, 3-5). In light of Vallée Poussin's explanation, I conclude two goals for Vasubandhu to preach on Consciousness-only: clearing the wrong view of conceiving self and objects as svabhāva (as in the first purpose) and clarifying the correct view of Consciousness-only (as in the second and third purposes). Those who could not correctly understand the doctrine of Consciousness-only are ordinary people, senika heresy (as in the second purpose), and clergy from other Buddhist schools (as in the last purpose). These Buddhist schools are Sarvāstivāda (external objects or the bāhyārtha have real existence as consciousness), Madhyamaka (inner consciousness, as external objects, do not exist), early Yogācāra (all consciousnesses derive from one original consciousness).

${ }^{11}$ For the translation of the $M M K$, I mainly consult the Chinese translation from Kumārajīva and the English translation from Siderits and Katsura. The Chinese translation is “不生亦不滅, 不常亦不斷, 不一亦不異, 不來亦不出” $M M K$ 1:1-2 (T30N1564, P1b14-15). Siderits and Katsura translate directly from Sanskrit that "neither cessation nor origination, neither annihilation nor the eternal, neither singularity nor plurality, neither the coming nor the going" (Siderits and Katsura 2013, 13). However, I conjecture that regarding the characteristics of dependent co-arising (pratītyasamutpāda), it is more suitable to translate them as adjectives, not nouns. Plus, I revise Siderits and Katsura's translation of the third pair of neither-nor into neither identical nor different insofar as it alludes to the identity of dharmas - as per Pingala, "if they are all identical, it is impossible to have cause and effect in the same way that if they are all different, they can not succeed one after another (若一則無緣。若異則無相續 )" (T30N1564, P2a4-5).

12 Given this definition of illusion, I interchangeably use 'illusion', 'illusory dharma', and 'illusory image'. 
This portrait might make little sense for common people. Mādhyamikas will find this confusion quite normal because our common sense entails only the conventional truth (samvrtisatya) about illusory dharmas. Eventually, we sublate common sense for the ultimate truth (paramärthasatya) in which we know emptiness as neither being nor non-being.

However, how is one to discern emptiness if emptiness becomes ineffable on the ultimate level? When scholars try to articulate the ineffability of emptiness, they fall into debate. In the Madhyamaka scholarship ${ }^{13}$, we can enumerate at least four explications of Nāgārjuna's emptiness. First, absolutists construe emptiness as the ultimate reality or the absolute noumena. All co-arising dharmas derive from the absolute noumena so that dharmas are relative phenomena (Murti 1955, 251). Truths about these relative dharmas are conventional. Since the conventional truth expresses nothing about the absolute reality, this truth becomes a "courtesy" (Murti 1955, 252). Eventually, for the ultimate truth of the absolute, this courtesy is to be 'sacrificed'. Some scholars attack the first reading for their substantializing of emptiness. For these scholars, emptiness is not an absolute reality but a pure void (Narain 1964, 316318). Since these scholars read emptiness as a negation of any possible existence, their reading is branded nihilism (Yao 2010, 85). For nihilists, although we can speak of emptiness (śünyatā) on the conventional level, ultimately emptiness is ineffable (Narain 1964, 336). Now that the ultimate truth of emptiness transcends languages and thinking, Nāgārjuna also embraces epistemic skepticism. This becomes the third or the skeptic reading - emptiness in Nāgārjuna nullifies concepts. After negating the conventional truth, we acquire a more objective view called the ultimate truth (Ganeri 2001, 43-47). In this understanding, skeptics allocate the ultimate truth in a logical order higher than the conventional one. Instead of giving another positive definition, anti-realists in the fourth reading define emptiness as the method of disputing $\bar{A}$ bhidharmic realism -what we hold to be true on the conventional level is merely conceptually constructed; eventually, "we cannot give content to the metaphysical realist's notion of a mind-independent reality" (Siderits 1988, 321-324). Therefore, emptiness is the way of rejecting viewing reality as mind-independent.

If the secretive saying or the negative approach shows the gist of Nāgārjuna's $M M K$, I conjecture that Nāgārjuna would find the fourth reading, a reading that is articulated negatively, more plausible. Let me explain first why the first three readings are not fully correct. If emptiness were a pure void and negated any existence, then nothing would exist and thus nothing could arise or perish. Contra the nihilistic reading and the skeptic reading, Nāgārjuna argues that emptiness is not a pure negation. Otherwise, emptiness could not be identical with the dependent co$\operatorname{arising}^{14}$. Nor would the four noble truths hold true ${ }^{15}$. Yet, on the other hand, if

\footnotetext{
${ }^{13}$ Here, I am indebted to our reading group on the $M M K$ organized by Dr. Antoine Panaïoti. He listed the four readings in the handouts for the first session of our reading group. We can also infer these four readings from his book Nietzsche and Buddhist Philosophy (Panaïoti 2013, 18). In order to facilitate the unfolding of my argument, I re-organize the order of the four readings.

${ }^{14}$ As Nāgārjuna says in $M M K$ 25:1-3, "if all dharmas were empty, there would be neither arising nor perishing. [If so,] Due to the terminating and perishing, what is nirvanna that is called (若一切法空,
} 
emptiness were an ultimate reality, this reality could not accommodate any changes. Likewise it could not permit arising and perishing. Contra the absolutist reading, Nāgārjuna depicts no absolute reality underneath all dependent arising dharmas ${ }^{16}$.

As Nāgārjuna says, "the dependent co-arising, we declare [it] to be emptiness. It is also a dependent concept; just that is the middle way" ${ }^{\prime 17}$ (T30N1564, P33b11-12). We see emptiness as such in the middle of an absolute nothingness and an ultimate reality - it is a non-duality of duality (a dichotomy advocated by absolutists between relative dharmas and absolute reality) and non-duality (the negation of the relativeabsolute duality) ${ }^{18}$. Thus, Sengrui remarks that the term 'middle' reveals the gist of the $M M K^{19}$.

Then, why the fourth reading is more plausible? As we have seen, by means of the middle way, Mādhyamikas depart from Hīnayāna teachings, a departure that advances Buddhist philosophy to another level. As Gadjin Nagao identifies, Madhyamaka elevates the conception of emptiness to the core of Buddhism through its radical critique of Hīnayāna realism as well as any metaphysical theories that are oriented with the dualistic view of being and non-being - nirvāna is no longer a higher reality or the antidote to samsāra because nirvāna neither affirmas nor negates samsāra (Nagao 1991, 213-214). Since Nāgārjuna uses emptiness to refute any dualistic views, he shall object to both metaphysical realism and idealism.

Although Nāgārjuna invalidates dualistic doctrines by his articulation of emptiness, he fails to make his arguments consistent. First, he renders the nature of co-arising dharmas on the conventional level ambivalent. If emptiness is identical to co-arising dharmas, how could dharmas be empty at the moment they co-arise? (Yao 2014, 320-321). Second, he makes the ultimate truth impossible for us to know. If there is an ultimate truth of emptiness as such, we would know it (Burton 1999, 4-5). Yet, how can we know an object qua emptiness when we cannot assume this object to

\footnotetext{
無生無滅者, 何斷何所滅,而稱為涅槃)? (T30N1564, P34c15-16) If all dharmas were not empty, there would be neither arising nor perishing. [If so,] Due to the terminating and perishing, what is nirvāna that is called (若諸法不空, 則無生無滅, 何斷何所滅, 而稱為涅槃) ? (T30N1564, P34c21-22) Neither acquired nor abandoned, neither terminate nor permanent, neither arising nor perishing; thus is nirvanna to be called (無得亦無至, 不斷亦不常, 不生亦不滅, 是說名涅槃)（ T30N1564, P34c26-27)".

${ }^{15}$ Nāgārjuna says in $M M K$ 24:1 that "if all dharmas were empty, there would be neither arising nor perishing. [If so,] how could the four noble truths exist (若一切皆空, 無生亦無滅, 如是則無有, 四聖諦之法)?” (T30N1564,P32b13-14).

${ }^{16}$ Nāgārjuna says in $M M K 24: 19$ that "there is no one single dharma that does not arise because of dependent co-arising. Thus, among all dharmas, there is no one that is not empty (未曾有一法, 不從 因緣生，是故一切法，無不是空者)”(T30N1564，P33b13-14).

${ }^{17} M M K$ 24：18 眾因緣生法，我說即是無。亦為是假名，亦是中道義.

${ }^{18}$ Here, I borrow the terminology of "nonduality of duality and nonduality" from Victor Hori. In his discussion of Kenshō, Hori uses this terminology to indicate that Kensho or satori is not merely a negation of dualistic thinking because this negation per se is still dualistic (Hori 2000, 285).

${ }^{19}$ Sengrui writes, "MMK has five hundred verses, composed by Bodhisattva Nāgārjuna. The title of the book is 'middle' that has already illuminated its content (中論有五百偈。龍樹菩薩之所造也以中為 名者。照其實也)” (T30N1564, P1a6-7).
} 
exist? The third problem is that of logical infinite regress. If the ultimate truth is the truth of a higher order because we acquire the ultimate truth by sublating the conventional truth, then we can continue to sublate this ultimate truth by another higher truth, so on ad infinitum. Given these problems, we do not know if Nāgārjuna really fails to define emptiness consistently or if he is using these inconsistencies to convince us of reason's limitation (Hayes 1989, 159; 166).

For Xuan Zang, it is not fully correct for us to articulate emptiness in a negative way. Rather, the secretive saying shall prepare us for the positive articulation of emptiness. Dharmas are empty because they are transformed by the underlying consciousness, not because this consciousness and its transformations have no existence. If we negate the existence of consciousness and its transformations, as per Xuan Zang (as well as Yao), we render ambivalent the nature of conventional truth. That is why the Buddhas deem anyone who conflates emptiness with the pure void to be incurable ${ }^{20}$.

On the basis of Mādhyamikas' implicit teachings, Yogācārins refashion the conception of emptiness by affirming the existence of consciousness. Gadjin Nagao depicts this positive approach to emptiness as Yogācārins' insight of "absolute emptiness and wondrous being" (Nagao 1991, 214). Fairly, Nagao conceives of the development from Madhyamaka's negative saying to Yogācāra's positive explicating as the maturation from Madhyamaka's "awareness of emptiness" to Yogācāra's conception of "absolute emptiness and wondrous being" (Nagao 1991, 214). Historically, however, it is a gradual process for Yogācāra to emerge out of and to eventually depart from Madhyamaka. In the transitional phase, as I shall show, although early Yogācārins accounted for emptiness as wondrous being, they failed to resolve Madhyamaka's inconsistencies. Because of their failure, Xuan Zang also categorizes early Yogācārins' teachings as 'not-so-correct readings of emptiness'.

Indian Buddhists portray the divide inside Yogācāra as such: early Yogācārins negate the existence of illusory images/dharmas but later Yogācārins affirm it. For this reason, they dub early Yogācāra nirākāravijñānavāda (Consciousness-only without illusory images) in contrast to later Yogācāra, the sākāravijñannavāda

\footnotetext{
${ }^{20}$ Xuan Zang responds to the third objection to vijñannaptimātra that "'Yet, regarding this vijñānaptimätra, is it not empty? If not, why?' Because it is not to be grasped or attached. It is so because by emptiness of dharma, we mean that dharmas, which are transformed by consciousness and are falsely grasped as real, are unattainable in principle. We say emptiness of dharma not because vijñannaptimātra, which is ineffable but can be realized by correct wisdom, does not exist. If consciousness as such does not exist, the conventional truth does not exist either. The inexistence of the conventional truth results in the inexistence of the ultimate truth. It is so because the conventional and the ultimate are interdependent. People who negate the twofold truth misunderstand emptiness. They are considered as incurable by the Buddhas. Thus, we shall know that all dharmas are empty and also not empty (此唯識性豈不亦空。不爾。如何。非所執故。謂依識變妄執實法理不可得說為 法空。非無離言正智所證唯識性故說為法空。此識若無便無俗諦。俗諦無故真諦亦無。真俗相 依而建立故。撥無二諦是惡取空。諸佛說為不可治者。應知諸法有空不空)” (T31N1585, P39b14-19).
} 
(Consciousness-only with illusory images) $^{21}$. Yao delineates a genealogy of this division as follows (Yao 2005, 122),

Nirākāravijñānavādin-Asanga—Vasubandhu—Sthiramati-Paramārtha and Bodhiruci Sākāravijñānavādin-Dignāga—Dharmapāla - Dharmakīrti—Xuan Zang and Kuiji

Let me now clarify the point earlier that early Yogācāra fails to fully distance itself from Madhyamaka. For early Yogācārins (such as Sthiramati and Nanda), all dharmas, all consciousnesses, all mental factors are transformed from one original consciousness so that all transformed illusions are false, characterized by the subjectobject duality ${ }^{22}$. Since illusions originate from the original consciousness, they have consciousness as their nature. Then, if consciousness has the same nature as illusions, it can not be ultimately real. That is why in the Sütrālamkārakārikēa, Asanga preaches, "nothing exists outside the citta; things do not exist, neither does the citta" 23 (T31N1604, P599a19). Asanga compares illusions to the light projected by the citta or by consciousness. Since the citta has the same nature as the light, if the light does not exist, the source of the light qua the citta does not exist either.

We shall raise our attention to early Yogācāra's phraseology in their articulation of emptiness. For early Yogācārins, illusions derive from consciousness so that they have consciousness as their nature. Since illusions are empty, so is consciousness. This wording is very similar to what Nāgārjuna advocates in the $M M K$-dharmas dependently co-arise from emptiness as dependent concepts; they are also emptiness; just that is the middle way.

Like Mādhyamikas, early Yogācārins also confront the same question: if illusions have consciousness as their nature and both do not exist, how could this

${ }^{21}$ Lü Cheng elaborates further on the distinction in this way: for early Yogācāra, Consciousness-only means that "both the grasping subjects (i.e. the seeing parts, jian-fen, 見分, darśanabhāga, ) and the objects being grasped (i.e. the seen parts, xiang-fen, 相分, nimittbhāga) have consciousness as their nature and both are falsely posited (古學所言唯識, 無論能取所取皆是識性, 皆是虛妄分別)” (Lü 1968, 75). For later Yogācāra, however, Consciousness-only means that "grasping subjects and grasped objects can have different natures but they still depend on consciousness(皆為所緣可別有性 , 但不離識故名唯識)”(Lü 1968, 76).

22 Xuan Zang writes "some say that the seen parts (nimittabhāga), etc. are transformed by consciousness but these transformations are not as real as consciousness in the dependent nature. Otherwise, the doctrine of Consciousness-only could not be justified because in this case, consciousness and external objects would have real existence (然相分等依識變現。非如識性依他中 實。不爾唯識理應不成。許識內境俱實有故)” (T31N1585, P59a6-7). As Vallée Poussin comments, for Xuan Zang, the first view comes from Nanda (Vallée Poussin 1928, 714). The last view is from Sthiramati, "some say that the seen parts (nimittabhäga), etc. have consciousness as their nature because consciousness transforms itself by force of perfuming as if consciousness encompassed these (seeing and seen) parts. Suchness is also the real nature of consciousness. Thus, nothing exists outside the nature of consciousness. The term consciousness (here) also covers the accompanied mental factors because these factors always associate with consciousness (或相分等皆識為性。由熏習力似多分生 。真如亦是識之實性。故除識性無別有法。此中識言亦說心所。心與心所定相應故)” (T31N1585, P59a15-17).

${ }^{23}$ Asanga writes, “心外無有物, 物無心亦無” (T31N1604, P599a19). 
transformation from consciousness to illusions happen in the first place? In early Yogācāra, the nature of illusory dharmas is still ambivalent because early Yogācārins do not affirm any existence of illusions. Due to their inability to remedy the ambivalence of illusions but also due to their negative demarcation of consciousness and illusions, early Yogācārins do not distance themselves from Mādhyamikas (Mei 2014, 345). Moreover, if illusions have consciousness as their nature, is consciousness another illusion or the underlying emptiness? To answer this question, early Yogācārins in China split into to sects. Daśabhūmika (di-lun-pai, 地论派) represented by Bodhiruci contends that among all eight consciousnesses, ālaya is half illusory half empty whereas Samgraha (she-lun-pai, 摄论派) represented by Paramārtha postulates emptiness as the ninth ādana consciousness outside all eight consciousnesses. Xuan Zang was determined to study Yogācāra in India because he wanted to bridge gaps between Daśabhūmika and Saṃraha.

Contrary to early Yogācārins who conceive of illusions as illusory light without any existence, Xuan Zang describes illusions transformed by consciousness to be "seemingly real as consciousness" 24 (T31N1585, P59a8). By seeming reality (xu-shi, 虛實), Xuan Zang means that illusions, despite being empty of svabhāva, still have a special way of existing. Otherwise, we could not explicate the nature of illusions at the exact moment they arise. Xuan Zang quotes the Madhyāntavibhāga that "the imagined (parikalpita) does not really exist. In order to indicate its non-realexistence, we metaphorically say it as names"25 (T31N1585, P47a10). As per Xuan Zang, these seemingly real illusions have nominal existence (jiayou, 假有, prajñaptisat). We attribute nominal existence to illusions because it facilitates our speaking and our thinking. Eventually, illusions are not real insofar as they constantly arise and perish.

However, since we are accustomed to names, we tend to imagine seemingly real illusions as permanently real, or, as svabhāva. In Buddhist terms, our imaginations pollute illusory dharmas ${ }^{26}$. To purify the pollution, we shall remove the false imagination from illusions that are transformed by consciousness. Illusions depend on the transforming of consciousness whether we falsely imagine them to be permanent or not. Transforming acts thus appear with a double identity: they generate pure dharmas that are not polluted by false imagination or they bring about polluted dharmas under false imagination ${ }^{27}$. "Yet, if the real dharmas do not exist, the nominal

\footnotetext{
${ }^{24}$ Xuan Zang writes, "both the seeing part and the seen part arise by force of dependent co-arising so that both depend on others and that they are seemingly real as consciousness (或識相見等從緣生。俱 依他起虛實如識)”(T31N1585, P59a8).

${ }^{25}$ Xuan Zang writes, “遍計所執都無體故為顯非有假說為名” (T31N1585, P47a10).

${ }^{26}$ In the last section, I will explicate that for later Yogācārins, what causes our suffering from attachments is not illusions per se but our wrong perception of illusions.

${ }^{27}$ Suguro Shinjò demarcates this hybridity as the neutrality of the second nature, a neutrality as the transparency that can either be tinted with false duality or be as purified from this false duality. Moreover, Suguro contends that this hybridity enables the objectification of mind in such a way that this objectification facilitates the explication of the pratibhāsa (manifestation) of consciousness (Suguro 1985, 152).
} 
dharmas do not exist either. It is so because the nominal posited on the basis of the real causes" ${ }^{28}$ (T31N1585, P47c12). Thus, Xuan Zang categorizes the existence of transforming acts as real (shi-you, 實有, dravyasat).

With regard to the underlying consciousnesses that keep transforming, Xuan Zang categorizes their existence as real in an absolute sense because their existence "is not posited on the basis of other causes and conditions" ${ }^{29}$ (T31N1585, P47c13). The imagined nature (parikalpitasvabhāva) of illusory beings, the other dependent nature (paratantrasvabhāva) of transforming acts, and the absolute nature (parinispannasvabhāva) of consciousnesses constitute the "three-nature account" (san-xing-shuo, 三性說) in the Siddhi.

In light of the three-nature account, Xuan Zang argues that what we imagine as substantial subjects and substantial objects are not svabhāva but seemingly real dharmas. These seemingly real dharmas are transformed by consciousness, constantly arising and perishing. In this sense, dharmas are empty, not svabhāva. All underlying consciousnesses, since they are the origins of transformation, are the truly empty. The defining nature of consciousnesses becomes this 'truly empty'. As Xuan Zang explains, "the term 'only' [in Consciousness-only] does not deny the dharmas dependent of consciousness. That is why truly empty etc. also have their nature" (T31N1585, P39a3-4). Thus, "ätman and dharma are not existents. The empty and the consciousness are not inexistent" 30 (T31N1585,P39b2). As we read in the Siddhi, Xuan Zang says later that "the nature of the two empties [empty of àtman and empty of dharma] is revealed as tathata, the suchness" (T31N1585,P46b14). Therefore, Xuan Zang has ipso facto referred to the nature of the true empty as emptiness, but also, as suchness, as tathatā (zhen-ru, 真如) ${ }^{31}$.

Xuan Zang's affirmation of the nature of the truly empty is further elaborated by his disciple Kuiji who differentiates the "empty" (kong, 空) from "emptiness" (kongxing, 空性). The empty, in Sanskrit, the śünya, is "an absence of twofold grasping (qu, 取, grāha)". In contrast, emptiness, śünyatā is the nature of the empty. The Sanskrit affix "- $t \vec{a}$ " denotes the meaning of "-ness" and thus "nature" (T44N1835, P2b25-29). This being said, our distinction between grasping subjects and grasped objects is a false duality (xu-wang-fen-bie, 虛妄分別, abhütaparikalpa $)^{32}$. We will elaborate on

\footnotetext{
${ }^{28}$ Xuan Zang writes, “若無實法假法亦無。假依實因而施設故”(T31n1585, P47c12).

${ }^{29}$ Xuan Zang writes, “圓成實性唯是實有。不依他緣而施設故”(T31n1585, P47c13).

${ }^{30}$ Xuan Zang writes, “唯既不遮不離識法。故真空等亦是有性” (T31N158, P39a3-4). That is why “ 我法非有空識非” (T31N1585, P39b2).

${ }^{31}$ In the verse “我法非有空識非無”, Vallée Poussin translates 《空識》 as 《la vacuité et la vijñāna 》 (Vallée Poussin 1928, 424). And as per Vallée Poussin, "la vacuité" is tathatā, the suchness. As we read in the Siddhi, “二空所顯真如為性” (T31N1585,P46b14). This suchness pertains to the last of the three-nature, the absolute nature, parinișpannasvabhāva.

${ }^{32}$ In the commentary of Vasubandhu's Madhyāntavibhāga (bian-zhong-bian-lun, 讋中邊論), Kuiji says, "suchness is the underlying nature of false-duality, thus the duality without twofold grasping. But we call it śunnya, if it is the absence of the grasping and the grasped. We call it śunnyata for which sinnya opens a door. The disclosed śünyatā is suchness. In Sanskrit, śünya is the name of empty; śünyatā is the name of suchness or emptiness. That is why we translate in Chinese the siunnyata as the nature of
} 
false duality in the last section. If we can empty this false duality from consciousness, we disclose the nature of truly empty consciousnesses, a nature called emptiness or suchness ${ }^{33}$. Thus, emptiness is the defining feature of consciousnesses that keep transforming, albeit we no longer pose on this transformation any false duality. Due to its constant transforming, even truly empty consciousness is not a svabhāva but a dynamic flow in constant change as waterfalls and torrents.

In this articulation of emptiness, Xuan Zang affirms the existence both of consciousnesses (i.e. true nature of being empty) and of illusory beings (i.e. the nominal existence or seeming reality). Consequently, Xuan Zang bestows on emptiness a twofold meaning: first, we realize that illusory dharmas are empty and have only nominal existence; then, we remove falsely imagined nature from these illusions in order to reveal the nature of being empty, namely, emptiness. This realizing and revealing conform to that which Nagao depicts as the "absolute emptiness and wondrous being" (Nagao 1991, 216).

When Xuan Zang translated Indian texts he brought back to China, he also set up the standard terminology for Chinese Buddhism. This terminology subtly enriches the meaning of Buddhist concepts. In the elaboration of emptiness, Xuan Zang borrows several Chinese categories in order to reinforce the twofold meaning of emptiness. He translates existence of empty illusions and the nature of consciousness by several pairs in Chinese philosophy, such as Yong (用, the functions of the substratum) and Ti (體, the underlying substratum), or, Xiang (相, the images determined by the nature) and Xing (性, the determinative nature). When Xuan Zang articulates emptiness as the Xing or the nature of consciousness, he also translates illusions as the Xiang, the images. By translating the Sanskrit term 'lakșana' (the characteristics) ${ }^{34}$ into 'Xiang' (image), Xuan Zang reinforces the idea that illusions are not non-existent but we can positively refers to them as images due to their nominal existence ${ }^{35}$.

empty (真如是妄分別體故無二取也。但言空者。即二取無。言空性者。以空為門。顯空性即真 如也。梵云瞬若。但名為空。言瞬若多故。說真如名空性也。以多此翻是性義故)”(T44N1835, P2b25-29).

${ }^{33}$ Kuiji's demarcation of the twofold meaning of emptiness can be also inferred from Xuan Zang's explication of ultimate no-nature as suchness in the Siddhi.

${ }^{34}$ It seems that many interpreters of Xuan Zang undervalued Xuan Zang's creative way of translating. This undervaluing can be seen through the translation of 'Xiang' (相) in the English version of the Siddhi. Vallée Poussin chooses to keep the Sanskrit terms or he translates it into "caractère" (the literal meaning of lakșana) so that he did not pay special attention to the nature-image pair. Cook translates 'Xiang' (相) into 'form', in which the relation between nature and image is lost. Cook's translation can be supported by the Chinese translation of the term "form" in modern Chinese - modern Chinese scholars translate Plato's theory of form into 相论 (the doctrine of form). However, in western philosophy, form is usually paired with matter and in this form-matter pair, it is hard to say which one is the determiner - as we see in the debates between realists and nominalists. In contrast, Chinese traditional philosophy conceives of nature as the determiner of images. Thus, Cook's translation of 'laksana' shadows the creativity of Xuan Zang's wording. Some scholars consider Xuan Zang's translation as an important step of sinicizing Indian Buddhism.

${ }^{35}$ Then, Xuan Zang is able to articulate the three-non-nature theory as follows: In virtue of this wording, the first imagined nature becomes the appearing or manifesting (pratibhāsa) images of consciousness in such a way that these images (lakșana) are not svabhāvatā (lakșaṇa nihsvabhāvatāa). 
Xuan Zang's vantage point of being affirmative differs from Madhyamaka. Not just does illusion have seeming existence; consciousness also has its nature of being. We also distinguish later Yogācāra from early Yogācāra by their respective degrees of affirming existence. In the Chinese context, Xuan Zang offers an understanding of emptiness different from Daśabhūmika and Samgraha - emptiness is not the eighth consciousness as Daśabhūmika advocates; nor do we need to follow Samgraha's postulation of a ninth consciousness. Rather, emptiness is the defining feature of unpolluted consciousnesses.

The next question we will pose on Yogācāra is whether it can solve problems in Madhyamaka's account of emptiness in a more satisfactory way than early Yogācāra. Recall the three problems in Madhyamaka's conception of emptiness: the ambivalent nature of the conventional truth, the unknowability of emptiness, and the logical infinite regress. For the first problem, Yogācārins formulate the three-nature account to accommodate Madhyamaka's twofold truth. As per Xuan Zang, the conventional truth contains three senses: the nominal conventional (jia-shi-su, 假世俗, prajñatisamvrrti) expressed by the imagined nature, the operational conventional (xing-shi-su, 行世俗, pratipattisamvrti) shown by the other dependent nature, and the revealing explicit conventional (xian-liao-shi-su, 顯了世俗, udbhāvanāsamvvrti) conveyed by the absolute nature (T31N1585, P47b29). Xuan Zang confers the conventional truth on all three natures whereas the ultimate truth resides only in the absolute nature (T31N1585, P47c4). Now that the conventional truth encompasses the nominal existence of illusions and the real empty nature of consciousness, the nature of dharmas in the conventional truth is no longer ambivalent. For the second problem, since emptiness becomes the nature of consciousness and has its distinct existence, emptiness can serve as the object of knowledge. Finally, regarding the last logical problem, if ultimate truth resides in the absolute nature, any truth in the higher order would be accommodated by the third nature. Hereby, later Yogāaārins dissolve the infinite regress.

If we want to realize the truly empty nature of consciousness, we must make constant effort to empty false duality. Our making-effort alludes to the importance of subjectivity on the epistemic level and of subjective agency on the practical level. When we return to this point in the last section, we will see how this affirmation of subjectivity in later Yogācāra alludes to the development of Yogācāra's epistemology (Lü 1986, 74). ${ }^{36}$ After clarifying that emptiness for Xuan Zang is not a pure void but a wondrous being, we can continue to examine whether Husserl's phenomenological essence is compatible with Xuan Zang's conception of emptiness.

\footnotetext{
A manifestation as such is also not svabhāva (utpatti nihsvabhāvatā) since images arise because of dependent co-arising. The absolute nature of consciousness is also not svabhāva (paramārtha nihsvabhāvatā), because even unpolluted consciousness is constantly transforming itself and the nature of these unpolluted consciousnesses qua emptiness is not substantial (T31N1585, P48a11-26)

${ }^{36} \mathrm{Fu}$ Xinyi depicts this development as the paradigm shift from early Yogācāra's philosophy of life about suffering and attachment, to later Yogācāra's epistemology (Fu 2006, 157). I will present this change in the last section.
} 


\section{ESSENCE AND TRANSCENDENTAL IDEALISM IN HUSSERL}

For Husserl, phenomenology is the science of essence. By essence, Husserl means something that is "accessible to the inquiring", not a "mystical metaphysical essence", nor a sui generis being (Hua 6/217). In other words, essence is not a metaphysical noumenon that transcends our knowledge. Rather, essence is what we can know. As I shall argue in this section, for Husserl, essence is the ideal sense.

Before turning to Husserl's conception of essence, I would like to, first, clarify Husserl's account of transcendental idealism in which essence is contextualized. In the current Husserlian scholarship, we can pinpoint three main readings of Husserl's transcendental idealism: the epistemological reading from David Carr; the metaphysical reading from A.D. Smith; and the critical reading from Dan Zahavi.

First, in the epistemological reading, Carr advocates that Husserl's transcendental idealism is metaphysically neutral, "not part of the metaphysics of the subject" (Carr 1999, 133). Carr's main argument is that by means of phenomenological reduction called epoché, Husserl has ipso facto suspended the natural existence of the world so that for Husserl "it (the transcendental subject) does not determine the world's being" (Carr 1999, 134). Yet, in his later period, Husserl did address many metaphysical issues. Regarding these later writings, Carr conjectures that either Husserl is pondering upon other ways to develop phenomenology into a rigorous science or Husserl is unconsciously denying the scientific feature of phenomenology (Hua 6/xxxi). By reading transcendental idealism as metaphysically neutral, Carr understands this transcendental idealism as a development of Cartesian dualism following Descartes, Husserl closes the transcendental realm off from the empirical realm.

The cost of this dualism, which Carr also finds in Kant, is the paradox of subjectivity. It is a paradox because humans can not be both transcendental subjects external to experience and empirical objects internal to experience, at the same time (Carr 1999, 134). The second or the metaphysical reading is able to resolve this paradox. Yet, Carr implicitly accuses this metaphysical reading of pushing "Kant and Husserl in the direction of metaphysical idealism" (Carr 1999, 137). By metaphysical idealism, Carr means the doctrine for which the real world can be reduced to mental phenomena (Carr 1999, 108). This is, exactly, the position of the second reading, propounded by A.D. Smith. According to Smith, "for him (Husserl), nothing 'outside' subjectivity" means that "if consciousness did not exist, nothing would" (Smith 2003, 179). Smith continues to explain that "nothing outside subjectivity" shows "all objective physical objects remain immanent to consciousness" (Smith 2003, 182). Because of this immanence, I find Smith's reading closer to a monism in the Fichtean sense.

Unlike Carr and Smith, Dan Zahavi initiates the third or the critical reading. As per Zahavi, Husserl neither absolutely bestows the metaphysical primacy on subjectivity (as in Smith's metaphysical reading) nor completely neutralizes metaphysical issues (as in Carr's epistemological reading) (Zahavi 2010, 75-78). Rather, Zahavi interprets Husserl's idealism as the opponent to metaphysical realism 
(Zahavi 2010, 85-88). Thus, Zahavi articulates Husserl's transcendental idealism as the "rejection of metaphysical realism" (Zahavi 2010, 85). As we have seen earlier in the debates on Nāgārjuna, metaphysical anti-realists refuse to view the world as nonsensible or mind-independent ${ }^{37}$.

Undoubtedly, we do not have to opt for epistemology against metaphysics or vice versa. Rather, we locate a spectrum between the epistemological reading and the metaphysical reading in Husserl's conception of transcendental idealism. As Dermot Moran interprets, early and late Husserl presented two versions of transcendental idealism. In contrast to early Husserl who inclines to be more metaphysically neutral, late Husserl tends to revitalize metaphysical idealism (Moran 2012, 227-237). Nevertheless, Husserl is a phenomenologist who explicates his position more straightforwardly than Mādhyamikas. Therefore, if we leave Husserl at the critical reading, it is slightly unfair. On the basis of Zahavi's demarcation of what Husserl's transcendental idealism is not, I want to positively account for what this idealism is. To do so, I begin with an elucidation of Husserl's conception of existence/being.

Husserl uses the term existence in two different ways: existence in the naturally real sense and existence in the transcendentally phenomenal sense. By natural existence, Husserl means the existence of actual reality in the natural spatial-temporal order, be it humans, animals, or inorganic bodies. Since we naturally exist in this way, as per Husserl, we take this natural existence as "straightforwardly existing" (Husserl 1/21). This natural existence will be bracketed or suspended when we enact phenomenological reduction called epoché. Afterwards, objects appear by means of the second type of existence in our consciousness. Yet, what is this existence? According to Husserl, phenomena in consciousness are not passively given to us from the outside but are continuously constituted by our subjectivity. Due to this constitution, existence of phenomena is not as real as the natural one but remains transcendentally ideal. Because of this ideality, we can not always locate phenomenal existence, such as the fictional existence, in the natural world. Nevertheless, Husserl insists that "natural being is a realm whose existential status is secondary" because "it continually presupposes the realm of transcendental being" (Hua 1/60). By this Husserl means that real objects can be meaningfully intended by us only on condition that they can appear in our consciousness as phenomena. Since naturally real being

\footnotetext{
${ }^{37}$ In a very recent paper, Hilary Putnam intends to differentiate two types of metaphysical realism: hardcore metaphysical realism ("as a term for a specific position whose main feature was the insistence that the world can be divided into mind-independent objects and properties in exactly one way") and liberal metaphysical realism (for which "representation is a relation between organisms and real things, properties and events) (Putnam 2015, 318; 325). Under these two types of metaphysical realism, Putnam identifies two kinds of naturalism: the former to scientific naturalism for which truth is justified by natural, physical laws whereas the latter to liberal naturalism for which truth can not be reduced to causality but is grounded in the possible references (Putnam 2015, 312; 322). Nevertheless, Putnam's differentiation is very new. For Husserl, naturalism is not Putnam's liberal naturalism but the scientific, hardcore naturalism. Mutatis mutandis, when Zahavi and Siderits use the term "metaphysical realism", they mainly refer to Putnam's hardcore metaphysical realism, not the liberal one.
} 
presupposes transcendentally phenomenal being, we find the two types of existence correlated. They are neither independent nor reducible to one another.

Consequently, we find Husserl standing in between Carr's epistemological reading and Smith's metaphysical reading. This being said, Husserl is not entirely metaphysically neutral because without out subjectivity, objects cannot be meaningfully intended; he distances himself from metaphysical idealism because the natural existence of empirical reality is not immanent to consciousness; he also disputes metaphysical realism in that subjectivity determines the phenomenal existence of objects. Natural existence is not mind-independent insofar as "it (natural being) continually presupposes the realm of transcendental being" (Hua 1/60). Thus, it is reasonable for Zahavi to demarcate Husserl as a metaphysical anti-realist.

After elucidating what Husserl's transcendental idealism is not, I proceed to outlining what it is. I consider Husserl's transcendental idealism as a correlative dualism that is much weaker than the Cartesian one. I will come back to this contrast between Husserl and Descartes further on. Now, to be more specific, I pinpoint three defining features of Husserl transcendental idealism: (1) Husserl neither negates the empirical reality of objects nor advocates that all physical beings are immanent in consciousness; (2) by affirming the natural existence that is psycho-physical, Husserl tries to warn us of the danger of seeing only natural existence and of forgetting the phenomenal existence; (3) the antidote to this forgetting is epoché by which we enter the transcendental realm and connect ourselves to the world. By virtue of this subjectivity, we constitute the transcendental realm on the condition of which the psycho-physical world can correlate to our consciousness and can appear as mental phenomena for us. This correlation makes the world meaningful to us. Once we attain this meaningful life, we liberate ourselves from the natural attitude. This liberation thus alludes to the way in which transcendental idealism "enlightens" us (Moran 2012, 241).

Now, let me clarify the point earlier that Husserl's transcendental idealism is a much weaker dualism than that in Descartes. The standard reading of Cartesian dualism is that through his meditations, Descartes closes subjective mind off from the objective world. However, we do not find the same closing-off in Husserl. By rejecting both metaphysical idealism and realism, Husserl considers transcendental ideality and empirical reality as two interdependent facets of the same life. For Husserl, our mind, the subjective mind is not Ryle's "ghost in the machine" or a mad doctor's "brain in a vat" but metaphysically open to objective reality. ${ }^{38}$ Because of

\footnotetext{
${ }^{38}$ Unlike Carr who claims that Husserl is reaffirming the Cartesian dualism, I think Husserl follows Descartes but goes beyond him. Let us recall Husserl's Cartesian Meditations. In this lecture, Husserl keeps stressing that we need a "transformation of the old-Cartesian meditations" and a "new beginning" (Hua 1/49-50). Thus, Husserl intends to depart from Descartes, not merely following him. As Iso Kern identifies, Cartesian meditation is just one of the three ways for Husserl to begin the phenomenological reduction (Kern 1964, 196). In this regard, David W. Smith dubs Husserl's idealism "dependent idealism" or "transcendental relativism" to gloss the relative sense of Husserl's ontological and metaphysical position (David W. Smith 2007, 168-181). I think my use of dualism is closer to David W. Smith's demarcation.
} 
this openness, Husserl's transcendental idealism goes beyond the Cartesian dualism. Like Moran portrays, each ego lives a "double life"39: we live in the real psychophysical world that is intersubjectively accessible but we also live in a world where subjectivity (or intersubjectivity) functions as the condition for all possible experience and as the determiner of the sense of the natural reality for us.

In his Buddhist Phenomenology, Lusthaus highlights that Yogācāra is a transcendental idealism in the Husserlian sense, not in the Kantian sense. Instead of elaborating on this demarcation, Lusthaus only asserts that Husserl's transcendental idealism differs from Kant's insofar as Husserl does not postulate the split between phenomenon and noumenon (Lusthaus 2003, vii-viii). However, as Philipp Berghofer argues, whether we can juxtapose Kant and Husserl as polar opposites largely depends on the way in which we interpret the two philosophers (Berghofer 2015, 155). If we follow the standard reading of Kant's transcendental idealism, championed by P.F. Strawson and H.A. Prichard that Kant separates the transcendental realm from the empirical realm, we find Husserl radically different from Kant. However, if we do not follow this two-world reading but opt for Henry Allison's one-world reading that the transcendental and the empirical are two sides of one same world ${ }^{40}$, we suddenly realize that Kant's transcendental idealism is quite close to Husserl's (Crowell 2001, 236). I contend, therefore, that we can keep open the meta-epistemological question whether Husserl articulates transcendental idealism differently from Kant. Yet, we will never question the disagreements between Kant and Husserl on their cognitive architectonics - in their epistemology, Kant stresses more conceptuality because intuition must be unified by understanding before being represented to mind whereas Husserl prioritizes intuitions in that any meaningful concepts find their ground in intuitions (KrV A99, B143; Hua 19/699).

Now that we have elucidated Husserl's conception of idealism, we can proceed to clarifying his idea of essence which will enable us to justify the compatibility between the Husserlian essence and the Buddhist doctrine of emptiness. In his pretranscendental period, Husserl uses the term essence to attack psychologism. Husserl introduces the concept of "essence" in Logical Investigations, when inquiring into the identity of various mental presentations of the same given object - how do we know that we perceive the same object even when our perception of that object varies from time to time and from place to place? Psychologists such as Brentano attribute this cognitive identity to "empirical contingencies of the course of consciousness", that is, to real psychological activities (Hua 19/704). However, Husserl argues that

\footnotetext{
${ }^{39}$ Moran writes, "human beings are physical, corporeal objects in physical, corporeal world" but "the world has 'being and sense' not because of this physicality, but precisely because of the achievements of the transcendental ego and indeed the open-ended plurality of transcendental egos acting in consort" (Moran 2012, 239)

40 Allison advocates that transcendental idealism prescribes the universal condition for human knowledge whereas empirical realism affirms real inter-subjectively accessible objects in spatiotemporal order. In contrast, transcendental realism postulates the existence of non-sensible noumena in itself, and empirical idealism, similar to psychologism, equates ideality with private data of the individual mind (Allison 1983, 6-7). We can find textual support in the "Fourth Paralogism of Ideality" for Allison's one-world reading ( $\mathrm{KrV}$ A369-370).
} 
sometimes, the object of knowledge does not have real, empirical existence. Examples of these objects are fictional beings, such as unicorn or vampire, or those in our memory. Considering these counterexamples, Husserl advocates that identical knowing should be guaranteed by "intentional and epistemic essence" (Hua 19/704). By essence, Husserl means the underlying identical sense (intuitively as that of "what object it is meant") or meaning (conceptually as that of "in what sense it is meant") of mental presentations in our consciousness (Hua 19/499). If essence amounts to the identical sense or meaning, it always entails more than what is really in front of us, more than what we can really observe or recorde. Due to this 'more than', we can never reduce essence to psychological activities.

After clarifying the condition of identical knowing, Husserl proceeds to investigating conditions of knowledge in general. Clearly, what make our knowledge possible can not be psychological laws. Otherwise, we would not be able to envisage fictional objects. Then, where does our knowledge come from if knowledge is not issued by laws abstracted from mental activities? According to Husserl, these laws are those that confer senses on real objects. Husserl considers these laws to be purely logical, not psychological, because they present "us [with] not what is generally wont to be in this or that province of the real, but what absolutely goes beyond all wont and all divisions into spheres of reality" (Hua 19/704). By saying this, Husserl implies that pure logical laws are not real - they are ideal. Since the ideal gives sense to the real, pure logical laws become the ground for psychological laws (Hua 19/705).

Husserl, in his pre-transcendental period, focuses more on critiquing psychologism. He does not clarify the antidote to psychologism, although he implies it by contrasting the psychological/real with the pure/ideal. After his transcendental turn, Husserl makes explicit this antidote qua transcendental idealism. Therefore, it is fair to say that Husserl's reflection on psychologism gradually nourishes the mature form of transcendental phenomenology.

This transcendental turn, as is mentioned in the introduction, is marked by the release of his Ideas1 in which Husserl contests not just psychologism but also naturalism. What characterizes naturalism is the way in which it presupposes the world to be pregiven and mind-independent. The naturalistic worldview gives rise to modern physicalism. For physicalism, the world is a mind-independent thing-in-itself that runs under physical laws. Husserl describes that physicalism views object as "individual object as such, a 'This here', an object never repeatable; as qualitied 'in itself" "(Hua 3/13). Since the world is mind-independent, we can never be sure about our perception of external objects. What we are able to know is merely representations inside our mind. In this way, our knowledge becomes the product of psychological activities. This view of knowledge conforms to that which we mentioned earlier - psychologism. For psychologism, any knowable object is merely "something real individually" that exists as the "experienceable, real actuality" (Hua 3/13, 3/40). Psychologism and physicalism become two correlated sides of the same coin qua naturalism.

Husserl finds this naturalistic worldview rather dangerous because under this worldview, we take the mind and the world as pre-given without even being able to 
question this pregiven-ness. Due to this inability, Husserl portrays humans in the natural attitude as "naïve" (Hua 3/79). For Husserl, if we naively assume the world as such to be a pre-given mechanism under natural laws, we lose our connection to the world. Subsequently, we also lose the chance of attaining the genuine meaning of life, because natural laws grant us "merely 'empirical' meaning, the meaning of a mere "matter of fact"' (Hua 19/706). Mutatis mutandis, in Husserl's terms, "a relation [as the psychological law] to our mental organization, or to consciousness in general (understood as the aspects of consciousness common to men in general), does not define the pure and the genuine" (Hua 19/706). If we degrade mental activities to the automatic generation of psychological laws, we miss the genuine meaning of consciousness.

What defines "the pure and the genuine" is the science of essence, namely, phenomenology. Phenomenology never stops at matter of facts. Nor does it oppose itself to factual sciences. Rather, phenomenology lays the ground for factual sciences because any naturally exiting fact presupposes the essential phenomenological existence. As Husserl says, "everything belonging to the essence of the individuum, another individuum can have too" (Hua 3/14). Underlying these real matters, essence is the eidetically universal which "delimits 'regions' or 'categories' of individua (Hua 3/14). By eidetic universality, Husserl means that essence is that which we can intuit universally from phenomena given in consciousness. "Essence is a new sort of object... the datum of eidetic intuition" (Hua 3/ 16). Here, we must notice Husserl's stress of constitutive subjectivity - essence is not passively given in intuition; rather, essence is that which we put into an idea after we find in the given "that is proper to an individual itself as its what" (Hua 3/14). Essence, therefore, is the "ideation" of contingent matters of facts - it is the ideal sense that we find universal to the real senses of matters of facts or, in short, universal to "matters-of-fact-ness" (Hua 3/13).

I want to explicate the relation between essence and transcendental idealism by referring back to epoché. As is mentioned earlier, Husserl devises epoché as the antidote to the natural attitude. Epoché puts three things into brackets: first, the natural world; second, "judgments about the spatio-temporal beings"; third, "all the sciences relating to [the] natural world" (Hua 3/65). Before epoché, things exist in the psycho-physical natural order. "Nothing else but the natural world is seen" (Hua 3/68). Through epoché, we suspend the natural existence of the world. Subsequently, we also neutralize our judgments about the natural world. Thus, after epoché, we make the world an intelligible phenomenon for us (Hua 3/68). In the process of enacting epoché, we dwell back to our pure consciousness, in which objects appear as our mental phenomena (Hua 3/188). When we perceive these phenomena, our intuition reaches out to the world and makes the world an intelligible field. Every time the subject fixes eyes on an object, the intelligible field changes accordingly in order to make the intended object stand out. Through intuition, we build up intentionality between the intentional object or the noema and the intending, noetic act. Objectivity for Husserl, consequently, is not mind-independent. Instead, objectivity in pure consciousness is always ensured by subjective intuitive acts. The intuitive intelligible sense of objects becomes the ground for valid concepts or 
meaning-intentions ${ }^{41}$. The essence for Husserl is the intelligible sense or the ideal meaning of intentional objects that appear after epoché.

Here, we summarize four features of Husserl's conception of essence: first, essence is not a mind-independent substance; second, it is constituted by intuitive acts in the process of perception; third, essence is the ideal sense issued by subjectivity; fourth, essence guarantees objectivity of knowledge. Because of these four features, we can also say that essence is the product of transcendental idealism. Phenomenology as the science of essence, therefore, is ipso facto the phenomenology as transcendental idealism.

Husserl's break-through in Ideas 1 marks the advent of his transcendental phenomenology. He keeps expending the limit of transcendental idealism and consequently, the limit of essence. In the Inner Time Consciousness, Husserl replaces the twofold noesis-noema structure with the threefold ego-cogito-cogitatum (Hua 1/87). This solipsist schema further becomes intersubjective when Husserl continues to inquire into a "higher value-form of humanity" (Hua 27/54). These inquiries are exemplified by his analysis of socio-historical groups such as cultural communities in the Kaizo articles as well as his investigation of the transcultural life-world in the Crisis. Transcendental ideality for Husserl is no longer just about 'me' as the subject, but also about 'we' as collective subjects. Consequently, Husserl renders multidimensional the objectivity ${ }^{42}$. Since Husserl expands the dimension of subjectivity and objectivity, he also makes essence multi-dimensional. This being said, essence is not just that of individual perception (what perception means for me), but also that of individual temporality in life (what my life means for me), that of communal groups (what our communities mean for us), and finally that of all humans (what history and the world mean for humans) (Hua 6/100, 193; Hua 27/ 44).

To close my analysis in this section, I would like to return to the problem of essence. Given the four features of the Husserlian essence (mind-dependence; constructability; ideality; objectivity), I examine now whether Xuan Zang's account of emptiness can countenance Husserl's conception of essence. Recall the conception of emptiness in Xuan Zang. As I have clarified in the previous section, emptiness has a twofold meaning: realizing that illusory beings have only nominal existence, empty of permanent existence; removing false duality from illusions so as to reveal the truly empty nature of consciousnesses. This being said, Buddhist practitioners shall stop seeing the self and the world as substances, ceasing to view the relation between the self and the world as that between graspers and the grasped. If they succeed in doing so, they remove falsely imagined nature from illusions. Consequently, they see

\footnotetext{
${ }^{41}$ Husserl's conception of intuition differs strongly from Kant's. This also marks the divergence between Husserl's pure phenomenology and Kant's critical philosophy - for Kant, what is universal can only be grasped by concepts, not by intuitive acts, and concepts are already pre-made categories; mutatis mutandis, for Kant, objectivity is guaranteed by transcendental laws in understanding, not by that in intuition.

${ }^{42}$ As Gurwitsch remarks, Husserl's account of objectivity is multi-dimensional: from objectivity of individual perception, to that of socio-historical groups, and finally to that of the trans-socio-historical Lebenswelt (Gurwitsch 1966, 168).
} 
illusory dharmas as they really are, as constantly being transformed from consciousness, as continuous arising and perishing. In the conclusion, I will elaborate further on the way in which later Yogācārins articulate emptiness as the way of curing sufferings. Given this account of emptiness in later Yogācāra, we can see that essence in the Husserlian sense is compatible with Yogācāra's conception of emptiness, because (1) essence per se is not a substantial being nor a svabhāva; (2) essence never presupposes the substantial existence of subjects, objects, and their relation, because all three are constituted by flowing consciousness; (3) essence shows the ideal sense of objects that we obtain immediately in intuition so that essence ensures the authentic knowing of objects as they are. All these three meanings of essence conform to Xuan Zang's conception of emptiness. More importantly, essence demonstrates the way in which objectivity is grounded in transcendental subjectivity. This role of subjectivity in Husserl is also endorsed by Yogācāra - detaching false views and acquiring correct views call for subject's effort.

Now that Yogācāra's account of emptiness countenances the Husserlian essence, this result allows us to formulate a Buddhist phenomenology both on the epistemological level and on the meta-epistemological level.

\section{CONCLUSION: XUAN ZANG'S BUDDHIST PHENOMENOLOGY}

At the end of Section two, I mention the development of epistemology that further intensified the divide between early Yogācāra and later Yogācāra. To conclude my paper, I would like to contextualize this epistemological turn in theories of consciousness offered by Yogācārins. By examining these theories, I intend to articulate the way in which later Yogācāra's account of consciousness can be interpreted as a transcendental phenomenology in the Husserlian sense.

As is demonstrated in the introduction, Xuan Zang defines consciousness as vijñapti - the act for someone to know something distinctly. In Husserlian terms, consciousness for Yogācārins amounts to the intentional relation between subjective acts and objects to be known. Unlike early Yogācārins, Xuan Zang does not differentiate the original consciousness from others. Due to this non-differentiation, when Xuan Zang uses the term consciousness, he means all eight consciousnesses and their accompanied mental factors ${ }^{43}$ (T31N1585, P1a29). The way in which consciousness enables someone to distinctly know something is called the

\footnotetext{
${ }^{43}$ Xuan Zang writes, "all manifesting images are transformed by consciousness so that their existences are postulated. Consciousness means vijñāpti [namely, causing someone to distinctly know something]. This consciousness mentioned here also encompasses the accompanied mental factors (caitta) because these mental factors are always associated with corresponding consciousnesses (彼相 皆依識所轉變而假施設。識謂了別。此中識言, 亦攝心所, 定相應故)” (T31N1585, P1a29). In Yogācāra, the eight consciousnesses are these: first five consciousnesses pertaining to eyes, ears, nose, tongue and body, the sixth consciousness is mind, the seventh is kleśavijñanna or manas (the delusional self-consciousness), and the eighth is the alayavijñana (the warehouse consciousness). When each consciousness transforms into various images, several mental factors begin to function at the same time.
} 
“transformation of consciousness” (識轉變, vijñānaparin̄āma). Yogācārins clarify this transformation through the structure of consciousness. They formulate the structure in four ways, three recorded by Xuan Zang in the Siddhi and the other supplemented by Kuiji. While early Yogācārins provide the first two structures, the last two are offered by later Yogācārins.

Each of these formulations conveys its distinct epistemological and metaepistemological implications. The first account of the structure of consciousness comes from Sthiramati, defined by Kuiji as the "onefold structure (yi-fen-shuo, 一分 說)” (T43N1830, P242a25). By onefoldness, Kuiji means that Sthiramati articulates consciousness as svasamvitti (zi-zheng, 自證), namely, self-consciousness. Although Xuan Zang does not mention the onefold structure in the Siddhi, he implies it in one understanding of Consciousness-only_- "some say that the seen parts (nimittabhäga), etc. have consciousness as their nature because consciousness transforms itself by force of perfuming as if consciousness encompassed these parts" (T31N1585, P59a15). From these descriptions, we can infer that for Sthiramati, consciousness is the process of self-transforming into illusions. Due to this transformation, illusions, though seeming to be encompassed by consciousness, are empty. Since illusions have consciousness as their nature, if illusions are empty, so is consciousness. Therefore, Sthiramati conceives of emptiness as nullifying illusions.

In the second twofold structure (er-fen-shuo, 二分說), Nanda dichotomizes consciousness into two parts, the act of knowing called darśanabhāga (the seeing part qua subject) and the objects to be known called nimittabhagga (the seen part qua object) ${ }^{44}$. Xuan Zang explicates that for Nanda, "the seen parts (nimittabhäga), etc. are transformed by consciousness but these transformations are not as real as consciousness" (T31N1585, P59a6-7). Nanda's conception of Consciousness-only is supported by the Sütrālamkāra, in which the grasping act (grāhaka) and the grasped object (grähya) are compared to the illusory light of the citta/consciousness (T31n1604, P613b12). As we have mentioned in section two, if both grähaka and grähya are illusions transformed by consciousness, illusions have consciousness as their nature. Since illusions are empty, so is consciousness.

On the meta-epistemological level, both the onefold model and the twofold model contend that all dharmas, be it the act of transforming or transformed objects, are illusions originated from consciousness. As long as consciousnesses transform into illusory images, we falsely dichotomize consciousnesses into svabhāvic subjects and objects to which we attach (T31N1585, P45c22-25). For early Yogācārins, we suffer from attachments because we are under illusions. If we want to cure suffering by realizing emptiness, we shall dispel illusions from the original consciousness. Let me

\footnotetext{
${ }^{44}$ Xuan Zang introduces Nanda's account later in the elaboration of alaya, "yet, the impure consciousness, when it is born as the underlying substratum, it seems to appear as subjects and objects. It is the same for mental factors that accompany consciousness. What seems to be the object is called nimittabhagga, the seen part or the image part (of consciousness). What seems to be the subject is called darśanabhāga, the seeing part (of consciousness) (然有漏識自體生時。皆似所緣能緣相現。 彼相應法應知亦爾。似所緣相說名相分。似能緣相說名見分)”(T31N1585, P10a22-24).
} 
translate this view into western philosophical terms: all things are relative because they are originated from consciousness and shall be reduced to consciousness. Early Yogācārins, then, have in fact endorsed ontological monism ${ }^{45}$ (only consciousness really exists) and metaphysical idealism (nothing exists outside consciousness).

Unlike early Yogācārins, Dignāga puts forward the threefold structure (san-fenshuo, 三分說) - consciousness constantly flows as the underlying process qua svasamvittibhāga which transforms to the seeing act qua darśanabhāga and the seen object qua nimittabhāga. Therefore, for Dignāga, consciousness as the process of transformation differs from the transforming act and the transformed object.

In the Siddhi, Xuan Zang contrasts the threefold structure of consciousness in Yogācāra with that in Sarvāstivāda. As we have introduced in section two, Sarvāstivādins embrace Ābhidharmic realism and view the world as mindindependent. In their threefold structure, Sarvāstivādins "refer to external objects as àlambana (suo-yuan, 所缘, the object of knowledge); to nimitta-bhāga as ākāra (xing-xiang, 行相, function); to darśanabhāga as underlying dravya (shi, 事, events) [of receiving external objects], because darśanabhāga is the nature of consciousness and its mental factors" ${ }^{\prime 46}$ (T31N1585, P10b2-3). Thus, when consciousness enacts its $\bar{a} k \bar{a} r a$ of representing, external objects as alambana are directly given to us. The existence of these external objects does not depend on our consciousness.

I find this cognitive architectonic in Sarvāstivāda rather similar to that in naturalism. For Husserl, naturalism renders the external world independent of our consciousness. Naturalists account for cognition as reception of external objects in our mind. However, Dignāga identifies one problem in Sarvāstivāda's threefold structure. If cognizing means to receive external objects, how can we account for memories? In memory, the objects of recollecting do not exist at present but this "absence for now" never hinders us from recollecting these objects (T31N1585, P10b8-9). If we recall Husserl's attack of naturalism, we can see that Husserl's argument is similar to Dignāga's. Sometimes, although the objects of our knowledge do not have natural existence, we can still perceive them.

Xuan Zang is thus confident that once people understand the truth of Consciousness-only, they will turn to Yogācāra's threefold structure -“[Yogācārins] refer to the seen image (nimittabhāga) as the alambana; to the seeing act (darśanabhāga) as the $\bar{a} k \bar{a} r a$; to the underlying process of nimittabhāga and darśanabhāga as the event, namely, svasamvittibhāga" "T7 (T31N1585, P10b6-7). Now that consciousnesses flow like "torrents and waterfalls", they constantly transform into their own objects and the acts of knowing (T31N1585, P7c19). Here, we can

\footnotetext{
${ }^{45}$ Readers might already notice that in early Yogācāra's articulation, the original consciousness becomes an absolute reality. Paramārtha refers to this reality as the Tathägatagarbha. Further on, the Huayan school develops the conception of Tathägatagarbha whereas many Chan clergy accuse this conception of substantializing emptiness and thus of violating Buddha's teaching of emptiness.

${ }^{46}$ Xuan Zang writes, “執有離識所緣境者。彼說外境是所緣。相分名行相。見分名事。是心心所 自體相故”(T31N1585, P10b2-3).

${ }^{47}$ Xuan Zang writes, “達無離識所緣境者。則說相分是所緣。見分名行相。相見所依自體名事。 即自證分”(T31N1585, P10b6-7).
} 
pinpoint the major difference between the Sarvāstivāda and Yogācāra, that is, their conceptions of ălambana, of the object of knowledge. Unlike Sarvāstivādins who considers ālambana to be external real objects, Xuan Zang conceives of älambana as nimittabhāga, as images transformed by consciousness. While Sarvāstivādin's cognitive architectonic resembles that in naturalism, Dignāga's threefold structure resembles Husserl's ego-cogito-cogitatum

However, Dignāga's threefold model of consciousness is vulnerable to one problem - if self-consciousness qua svasamvitti is the ground for the seeing part and the seen part, what will be the ground for this self-consciousness? Without an answer, we might again fall into infinite regress - we can always locate a more fundamental ground for consciousness so on ad infinitum. Without such a ground, how can we be sure that we are conscious of our self-consciousness? Thus, as Xuan Zang explains, consciousness must have one more part to justify the existence of self-consciousness, through which we can be certain of our self-consciousness (T31N1585, P10b18-22). This fourth part is called the "awareness of self-consciousness" or the svasamvittisamvittibhāga (zheng-zi-zheng-fen, 證自證分). Since svasamvittisamvittt is svasamvitti's immediate intuitive awareness of itself, svasamvitti-samvitti and svasamvitti have the same nature. By supplementing svasamvittisamvitti, Dharmapāla advocates the fourfold structure (si-fen-shuo, 四分說) - the seeing part, the seen part, self-consciousness, and the immediate awareness of self-consciousness.

In light of their articulation of consciousness, Dignāga and Dharmapāla also provide a distinctive interpretation of false duality. This interpretation begins with the elucidation of attachments. As is mentioned earlier, in early Yogācāra, we suffer from attachments because we are under illusions. However, for later Yogācārins, illusions per se are not the cause of sufferings. Dharmas are illusory whose existence is seemingly real. This being said, dharmas, be it human mind or the external world in western terms, constantly arise and perish. This is how dharmas are - constantly changing, impermanent, and empty. These illusory dharmas are not directly of false duality. As per Xuan Zang, false duality is generated not by all consciousnesses but only by the sixth consciousness called the mind and the seventh consciousness called the manas. Through the mind, we conceptualize the world to be substantial whereas through the manas, we mistake the eighth consciousness for the unchanging svabhāvic self (T31N1585, P45c26). Later Yogācārins further elaborate on their account of false duality in the theory of pramāna ${ }^{48}$.

\footnotetext{
${ }^{48}$ As the theory of pramanna is beyond the main focus of this paper, I would provide a brief sketch of this theory. In each moment, consciousness generates the transforming act which then constitutes its distinct object. If transformed objects have seeming reality in only the current moment and this seeming reality soon vanishes in the next moment, authentic knowledge is momentarily gained through intuition. This portrait of intuitive knowing (pratyakșapramāna) in Dignāga resembles Husserl's account of intuition - intuition is the ground for intentionality and is the authentic thinking (Hua 12/193). All eight consciousnesses and their mental factors can generate their distinct intuitive knowledge of their respective objects from one moment to another. That is why Consciousness-only for later Yogācāra is not about one original consciousness but about all consciousnesses (T31N1585, P39c21). On the basis of intuition, humans always tend to extract concepts from intuitive knowing. Concepts render the identity of all things stabilized. By conceptual thinking (anumānapramāna), we
} 
Through this interpretation of false duality, we can see that for Xuan Zang, we suffer from attachments because we falsely conceptualize illusory dharmas into substances, not because consciousness transforms itself into illusory dharmas. Emptiness thus does not negate consciousness and its transformations. Rather, we realize emptiness as the nature of flowing consciousness after we understand the error of conceptualizing. In this way, for later Yogācārins, realizing emptiness becomes an epistemological question of seeing things as they are without false duality, not a metaphysical question of negating duality. This change becomes what I refer to earlier as the epistemological turn of Yogācāra. After the epistemological turn, later Yogācārins articulate subjectivity as the condition that bestows sense on nominal existence and that guarantees objective knowing of illusions.

Meta-epistemologically, since later Yogācārins dispute any mind-independent reality, they do not embrace metaphysical realism as Sarvāstivādins. Neither do they endorse metaphysical idealism as early Yogācārins in that later Yogācārins object to reducing the existence of illusory dharmas back to consciousness. Rather, we find that later Yogācārins affirm the nominal existence of illusions insofar as this shows how dharmas really are in empirical life. This objectivity of illusory dharmas is ensured by subjectivity that serves as the condition of the meaning of nominal existence. For later Yogcarins, seeming reality of illusions and transcendental subjectivity of consciousness are also two sides of the same life. In this life, we realize emptiness by cultivating genuine knowledge of how dharmas genuinely are and by dispelling false duality. Thus, we lay the foundation for Xuan Zang's Buddhist phenomenology that epistemologically articulates the intentional structure of consciousness and metaepistemologically entails transcendental idealism.

\section{ACKNOWLEDGEMENTS}

I want to express my gratitude to the two anonymous referees of Comparative Philosophy for their inspiring and insightful comments on the earlier version of this paper. I would also like to thank Isabel Essebag and Tianyu Zhang for proof-reading, Antoine Panaïoti for his help with Sanskrit. Finally, I hope to thank Le Programme de Bourses d'Excellence pour Étudiants Étrangers (PBEEE) from the Quebec government for supporting my research.

\section{REFERENCES}

Allison, Henry (1983), Kant's Transcendental Idealism: an Interpretation and Defense (New Haven: Yale University Press).

begin to attain the svabhāvic world-view under which our attachments are nourished. Among all consciousnesses, only the mind and manas have the capacity of conceptualizing. For this reason, only these two consciousnesses can generate false duality. 
Arnold, Dan (2005), Buddhists, Brahmins, and Belief: Epistemology in South Asian philosophy of religion (New York: Columbia University Press).

- (2012), Brains, Buddhas, and Believing: the Problem of Intentionality in Classical Buddhist and Cognitive-Scientific Philosophy of Mind (New York: Columbia University Press).

Burton, David (1999), Emptiness Appraised: A Critical Study of Nāgārjuna's Philosophy (Richmond: Routledge).

Berghofer, Philipp (2015), "Transcendental Idealism in Kant and Husserl. Different Lines of Interpretation and their Compatibility", in V. L. Waibel (ed.), Nature and Freedom, 12. International Congress of Kant-Gesellschaft and the University of Vienna, 21-25 September 2015, Vienna (Vienna: University of Vienna), 155.

Carr, David (1999), The Paradox of Subjectivity: The Self in the Transcendental Tradition (Oxford: Oxford University Press).

- (1987), Interpreting Husserl (Dordrecht: Springer Netherlands).

Chatterjee, Ashok Kumar (1962), The Yogācāra Idealism (Varanasi: Bhargava Bhushan Press).

Ch'en, K.S. Kenneth (1973), The Chinese Transformation of Buddhism (Princeton: Princeton University).

Crowell, Steven (2001), Husserl, Heidegger, and the Space of Meaning (Evanston: Northwestern).

Droit, Roger-Pol (1997), Le Culte du Néant: les Philosophes et le Bouddha, trans. David Streight and Pamela Vohnson (2003), The Cult of Nothingness: the Philosophers and the Buddha (Chapel Hill: University of North Carolina).

Fa Zang 法藏, Huayan-Yi-Cheng-Jiao-Yi-Fen-Qi-Zhang 《華嚴一乘教義分齊章》 [Paragraphs on the Doctrine of Difference and Identity of the One Vehicle of Huayan]. T1866.

$\mathrm{Fu}$, Xinyi 傅新毅 (2006), Xuan-Zang-Ping-Zhuan 《玄牀评传》[A Critical Biography of Xuan Zang] (Nanjing: Nanjing University Press).

- (2002), “Fo-Xue-Shi-Yi-Zhong-Ben-Ti-Lun-Ma 佛法是一种本体论吗? [Is Buddhist Dharma a Type of Ontology?]”, Nan-Jing-Da-Xue-Xue-Bao 《南京大学 学报》[Journal of Nanjing University], 39: 15-24.

Ganeri, Jonardon (2001), Philosophy in Classical India (New York: Rougledge).

Gurwitsch, Aron (1982), "Husserl's Theory of the Intentionality of Consciousness", in Hubert Dreyfus (ed.), Husserl Intentionality and Cognitive Science (Cambridge: The MIT Press), 59-72.

Hayes, Richard (1989), Dignäga on the Interpretation of Signs (Boston:Kluwer).

Hall, Bruce C. (1986), "The Meaning of Vijñāpti in Vasubandhu's Concept of Mind", The Journal of The International Association of Buddhist Studies, 9 (1): 7-24.

Hori, G. Victor (2000), "Kōan and Kenshō in the Rinzai Zen Curriculum”, in Steven Heine \& Dale Wright (eds), The Kōan: Texts and Contexts in Zen Buddhism, (New York: Oxford University), 280-315.

Husserl, Edmund (1931), Cartesianische Meditationen und Pariser Vorträge, trans. Dorion Cairns (1960). Cartesian Meditations (The Hague: Martinus Nijhoff Publishers). [Abbr. Crisis or Hua 1] 
- (1976), Ideen zu einen Reinen Phaenomenologie und Phaenomenologischen Philosophie, erstes Buch, trans. F. Kersten (1983). Ideas Pertaining to a Pure Phenomenology and to a Phenomenological Philosophy, First Book (The Hague: Martinus Nijhoff Publishers). [Abbr. Ideas1 or Hua 3]

- (1976), Ideen zu einen Reinen Phaenomenologie und Phaenomenologischen Philosophie, erstes Buch, trans. D. Dahlstrom (2014), Ideas for a Pure Phenomenology and Phenomenological Philosophy, Book I (Indianapolis: Hackett).

- (1976), Die Krisis der Europaeische wissenschaften und die Transzendentale Phaenomenologie [The Crisis of European Science and the Transcendental Phenomenology], ed, Walter Biemel (The Hague: Martinus Nijhoff Publishers). [Abbr. Crisis or Hua 6]

- (1959), Erste Philosophie (1923/1924), Erster Teil [First Philosohy, First Book], ed. Rudolf Boehm (The Hague: Martinus Nijhoff Publishers).

- (1959), Erste Philosophie (1923/1924), Zweiter Teil [First Philosohy, Second Book], ed. Rudolf Boehm (The Hague: Martinus Nijhoff Publishers).

- (1969), Zur Phaenomenologie der Inneren Zeitbewusstseins (1983-1917)[On the Phenomenology of the Consciousness of Internal Time], ed. Rudolf Bohem (The Hague: Martinus Nijhoff Publishers).

- (1970), Philosophie Der Arithmetik [Philosophy of Arithmetic], ed. Lothar Eley (Dordrecht: Kluwer Academic Publishers).

- (1968), Logische Untersuchungen, zweiter Bund, trans. J.N.Findlay (2001), Logical Investigations Vol2 (London: Routledge). [Abbr. Hua 19]

- (1989), Aufsätze und Vorträge (1922-1937) [Essays and Presentations], ed. Thomas T. Nenon and Hans R. Sepp (Dordrecht: Kluwer Academic Publishers). [Abbr. Hua 27]

- (2003), Transzendentaler Idealismus (1908-1921)[Transcendental Idealism], ed. Robin D. Rollinger \& Rochus Sowa (Dordrecht: Kluwer Academic Publishers).

Kern, Iso (1964), Kant und Husserl [Kant and Husserl] (Den Haag:M. Nijhoff).

- (2010), Das Wichtigste im Leben: Wang Yangming (1472-1529) und seine Nachfolger über die < Verwirklichung des ursprünglichen Wissens > 致良知 [The Most Important in Life: Wang Yangming (1472-1529) and His Followers on the Realization of Original Knowledge] (Basel: Schwabe Varelage).

- (2012), The Phenomenon of Mind trans. Ni Liangkang, Zhang Qingxiong, and Wang Qingjie, Xin-De-Xian-Xiang 《心的現象》[The Phenomenon of Mind] (Beijing: Commercial Press).

Kochumuttom, Thomas (1982), A Buddhist Doctrine of Experience (Delhi: Motilal Banarsidass Publishers).

Kuiji 窺基, Cheng-Wei-Shi-Lun-Shu-Ji 《成唯識論述記》[Kuiji's Interpretation of Cheng Wei Shi Lun].T1830.

- Bian-Zhong-Bian-Lun-Shu-Ji 《㖕中邊論述記》[Kuiji's Interpretation of Madhyāntavibhāga]. T1835.

Lin, Chen-kuo 林鎮國 (1999), Kong-Xing-Yu-Xian-Dai-Xing 《空性與現代性》 [Emptiness and Modernity] (Taiwan: Lixu Culture). 
Lü, Cheng 呂澄 (1986), Lü-Cheng-Fo-Xue-Lun-Zhu-Xuan-Ji-Yi《呂澄佛學論著選集 》(一) [The Selections from Writings of Lü Cheng on Buddhism. Vol.1] (Jinan: QiLu Press)

Lusthaus, Dan (2003), Buddhist Phenomenology: A Philosophical Investigation of Yogacara Buddhism and the Ch'eng Wei-shih Lun (New York: Routledge).

Madhyāntavibhāga. trans. Xuan Zang 玄牀, Bian-Zhong-Bian-Lun《辯中邊論》[The Clarification of the Middle Way]. T1600.

Mahāyānasūtrālamkārakārikā. trans. Prabhākaramita, Da-Cheng-Zhuang-Yan-JingLun《大乘莊嚴經論》[The Adornment of Mahayana Sūtras]. T1604.

Mei, Guangxi 梅光羲 (2014), Mei-Guangxi-Zhu-Shu-ji《梅光羲著述集》[Collective Writings of Mei Guangxi] (Shanghai: Dong-Fang Press).

Moran, Dermot (2005), Edmund Husserl: Founder of Phenomenology (Cambridge: Polity Press).

- (2012), Husserl's Crisis of the European Sciences and Transcendental Phenomenology: An Introduction (Cambridge: Cambridge University Press).

Mūlamadhyamakakārikā of Nāgārjuna. trans. Kumārajīva, Zhong-Lun 《中論》[The Commentary of the Middle Way]. T1564.

Murti, T.R.V. (1955), The Central Philosophy of Buddhism: A Study of the Madhyamaka System (London : George Allen and Unwin).

Nagao, Gadjin (1991), Madhyamaka and Yogācāra, trans, Leslie S. Kawamura (1991) (Albany: State University of New York Press).

Narain, Harsh (1964), "Śūnyavāda: A Reinterpretation", Philosophy East and West, 11(4): 311-388.

Ni, Liangkang (2010), "The Ultimate Consciousness and Ālaya-vijñāna: a Comparative Study on Deep-structure of Consciousness between Yogācāra Buddhism and Phenomenoogy" in YU Chung-chi (eds), Phenomenology 2010, vol.1: Selected Essays from Asia and Pacific: Phenomenology in Dialogue with East Asian Tradition (Bucharest: Zeta Books).

Panaïoti, Antoine (2013). Nietzsche and Buddhist philosophy (Cambridge: Cambridge University Press).

Pramānasamuccaya of Dignāga, trans. Fazun 法尊(1982), Ji-Liang-Lun《集量论》

[The Theory of Pramāna] (Beijing: Chinese Social and Scientific Press).

Putnam, Hilary (2015), "Naturalism, Realism, and Normativity", Journal of the American Philosophical Association, 1(2):312-329.

Samdhinirmocanasūtra. Trans. Xuan Zang 玄牀, Jie-Shen-Mi-Jing《解深密經》[The Explication of Mystery]. T676.

Schmithausen, Lambert (2005), On the Problem of the External World in the Ch'eng wei shih lun (Tokyo: The International Institute for Buddhist Studies).

Sharf, Robert (1993), "The Zen of Japanese nationalism”, History of Religions, 33(1): $1-43$.

Siderits, Mark (1988), "Nāgārjuna as Anti-Realist", Journal of Indian Philosophy, 16(4): 311-525. 
— and Shōryū Katsura (2013), Nāgārjuna's Middle Way: Mūlamadhyamakakārikās (Boston, Wisdom Publications).

Smith, A.D (2003), Routledge Philosophy Guidebook to Husserl and the Cartesian Meditations (London: Routledge).

Smith, David Woodruff (2007). Husserl (New York: Routledge).

Suguro, Shinjò 勝呂信靜, “唯識說的理論體系之形成 [The Establishment of Yogācāra's Theoretical System]”, in Takasaki, Jikido 高崎直道 (ed.) (1981), 《唯 識ライブラリー》[The Theories of Vijñānavāda],trans, Li, Shijie 李世傑 (1985), 《唯識思想》[The Theories of Vijñānavāda] (Taibei: Huayu Press), 109-156.

Tang, Yongtong 湯用彤 (2000), Sui-Tang-Fo-Jiao-Shi-Gao 《隋唐佛教史稿》 [Historical Materials of Buddhism in Sui-Tang Dynasties] (Shijiazhuang: Hebei People's Press).

Varela, Francisco J, Thompson, Evan, \& Rosch, Eleanor (1991), The Embodied Mind: Cognitive Science and Human Experience (Cambridge: MIT Press).

Vijñāptimātratāsiddhi of Dharmapāla et al, trans. Xuan Zang 玄牀, Cheng-Wei-ShiLun 《成唯識論》[The Commentary of Consciousness-only]. T1585.

— trans. Louis de La Vallée Poussin (1928-1929), Vijñaptimātratāsiddhi : La Siddhi de Hiuan-Tsang[The Siddhi of Hiuan-Tsang] (Paris, P. Geuthner).

- trans. Francis H. Cook (1999), Three Texts on Consciousness Only (Berkley: Numata Center for Buddhist Translation and Research).

Wayman, Alex (1965), "Review of the Yogācāra Idealism", Philosophy East and West, 15: 65-73.

Xia, Jinhua 夏金华 (2002), “Fo-Xue-Zhong-You-Ben-Ti-Lun-Xue-Shuo-Ma 佛学理论 中有“本体论' 学说吗[Is there an 'Ontology' in Buddhist Theories?]”, ShanghaiShe-Hui-Ke-Xue-Yuan-Xue-Shu-Ji-Kan 《上海社会科学院学术季刊》[Quarterly Journal of the Shanghai Academy of Social Sciences], 3: 133-139.

Yao, Zhihua (2005), The Buddhist Theory of Self-Cognition (New York: Routledge).

- (2010), "Typology of Nothing: Heidegger, Daoism, and Buddhism", Comparative Philosophy 1: 78-89.

- (2014), "Yogācāra Critiques of the Two Truths", in: Chen-kuo Lin \& Michael Radich (eds), A Distant Mirror: Articulating Indic Ideas in Sixth and Seventh Century Chinese Buddhism (Hamburg: Hamburg University Press), 313-334.

Yogācārabhümiśāstra trans. Xuan Zang 玄牀, Yu-Jia-Shi-Di-Lun 《瑜伽師地論》 [Discourse on the Stages of Yoga Practice]. T1579.

Zahavi, Dan (2003), "Phenomenology and Metaphysics", in D. Zahavi, S. Heinämaa \& H. Ruin (eds), Metaphysics, Facticity, Interpretation (Dordrecht: Kluwer Academic Publishers), 3-22.

- (2010), "Husserl and the Absolute", in Carlo Ierna, Hanne Jacobs \& Filip Mattens (eds), Philosophy, Phenomenology, Sciences (New York: Springer), 71-92.

Zürcher, Erik (2007), The Buddhist Conquest of China (Leiden: Brill). 